\title{
Partial characterization and inactivation of peroxidases and polyphenol-oxidases of umbu-cajá (Spondias spp.)
}

\author{
Caracterização parcial e inativação de peroxidases e polifenol-oxidases de umbu-cajá (Spondias spp.)
}

Cíntia Reis da SILVA ${ }^{1}$, Maria Gabriela Bello KOBLITZ ${ }^{1 *}$

\begin{abstract}
A crude extract of Spondias spp. was evaluated for the influence of $\mathrm{pH}$ and temperature on the activity and stability of its peroxidases and polyphenol-oxidases. In order to evaluate the conditions for the inactivation of the enzymes by heat treatment and by addition of a reducing agent, a factorial experimental design $(\mathrm{n}=3)$ was employed using the Statistica $(6.0)$ software package for data analysis. The optimal conditions found for peroxidases were: $\mathrm{pH}=5.0$ and temperature $=40^{\circ} \mathrm{C}$, and for polyphenol-oxidases they were $\mathrm{pH}=7.0$ and temperature $=40{ }^{\circ} \mathrm{C}$. The peroxidases and polyphenol-oxidases were stable at all $\mathrm{pH}$ values tested $(3.0-10.0)$ and maintained more than $60 \%$ of their activity at temperatures above 30 and $40^{\circ} \mathrm{C}$, respectively. To achieve the total inactivation of these enzymes, two alternatives can be suggested: incubation at $92{ }^{\circ} \mathrm{C}$ for 3.15 minutes with $200 \mathrm{mg} . \mathrm{L}^{-1}$ of ascorbic acid or incubation at $96^{\circ} \mathrm{C}$ for 2.80 minutes with $100 \mathrm{mg} . \mathrm{L}^{-1}$ of ascorbic acid.

Keywords: peroxidase; polyphenol-oxidase; Spondias spp.; inactivation.
\end{abstract}

\section{Resumo}

O extrato bruto de umbu-cajá foi avaliado quanto à influência do $\mathrm{pH}$ e da temperatura na atividade e na estabilidade de peroxidases e polifenol-oxidases nativas. Para avaliação das condições de inativação das enzimas por tratamento térmico e por adição de agente redutor (ácido ascórbico), foi realizado um experimento fatorial $(n=3)$ com aplicação do software Statistica (6.0) para elaboração da planilha de ensaios e das superfícies de resposta. Para as peroxidases, foram encontrados os seguintes parâmetros ótimos: $\mathrm{pH}=5,0 \mathrm{e}$ temperatura $=40^{\circ} \mathrm{C}$. E para polifenol-oxidases: $\mathrm{pH}=7,0$ e temperatura $=40^{\circ} \mathrm{C}$. Ambas as enzimas foram estáveis em toda a faixa de $\mathrm{pH}$ testada $(3,0-10,0)$, peroxidases e polifenol-oxidases mantiveram acima de $60 \%$ de sua atividade em temperaturas acima de 30 e $40{ }^{\circ} \mathrm{C}$, respectivamente. Para inativação total das enzimas em teste, duas alternativas foram sugeridas: $200 \mathrm{mg} . \mathrm{L}^{-1}$ de ácido ascórbico, $92{ }^{\circ} \mathrm{C} / 3,15 \mathrm{minutos}$ ou $100 \mathrm{mg}$. $\mathrm{L}^{-1}$ de ácido ascórbico, $96^{\circ} \mathrm{C} / 2,80$ minutos.

Palavras-chave: peroxidase; polifenol-oxidase; Spondias spp.; inativação.

\section{Introduction}

The genus Spondias (family Anacardiaceae) comprises 14 species found in the tropical regions of four continents (the Americas, Africa, Asia, and Oceania). Four main species are common in Brazil: "cajä" (Spondias mobim L.); "umbu" (Spondias tuberosa Arr. Cam.); "siriguela" (Spondias purpurea L.), and "umbu-cajá" (Spondias spp.), the latter is a natural hybrid formed between "umbu" and "cajä". All four species cited are trees which produce fruits that are widely enjoyed and have growing commercial markets for their pulp - which is used to produce juices and ice cream (USHIKUBO; WATANABE; VIOTTO, 2007; CEVA-ANTUNES et al., 2006).

The conservation of plant products both fresh and as processed material depends mostly on controlling the activity of two enzymes: peroxidase and polyphenol-oxidase. Peroxidases are oxidoreductases that catalyze reactions in which hydrogen peroxide (or other peroxide) functions as an electron acceptor while another compound acts as a donor. These enzymes are involved in the enzymatic browning of the plant tissues and the loss of color, flavor, aroma, and nutritional value of many products. Peroxidases are known for their thermo stability, usually requiring rigorous thermal treatment to be inactivated. This type of treatment generally causes undesirable alterations in the products and should be limited to only the minimum necessary (SERRANO-MARTÍNEZ et al., 2008; MARQUEZ et al., 2008; SHALINI; SHIVHARE; BASU, 2008; WHITAKER, 1994). Polyphenol-oxidases are the main enzymes responsible for the enzymatic browning of plant tissues. In the presence of oxygen, these enzymes catalyze a hydroxylation of monophenols to ortho-diphenols and the oxidation of these products to ortho-quinones which, in turn, polymerize and generate dark-colored compounds (red, brown, or black). Generally, these enzymes are found in chloroplast membranes, whereas the phenolic substrates are concentrated in vacuoles. Tissue damage will cause the cells to rupture and allow the enzymes and substrates to enter into contact resulting in the rapid oxidation of the phenolic compounds (TEIXEIRA et al., 2007; FANG et al., 2007; DOGAN, S.; TURAN; DOGAN, M., 2006; ZAWISTOWSKI et al., 1995).

Recebido para publicação em 21/10/2008

Aceito para publicação em 25/9/2009 (003889)

${ }^{1}$ Departamento de Tecnologia, Colegiado de Engenharia de Alimentos, Universidade Estadual de Feira de Santana - UEFS, BR 116-Norte, Km 03, CEP 44031-460, Feira de Santana-BA, Brasil,E-mail: mkoblitz@uefs.br

${ }^{*}$ A quem a correspondência deve ser enviada 
Since no information was found in the literature dealing with oxidative enzymes in fruits of the genus Spondias, the present work evaluated the peroxidase and polyphenol-oxidase activity of the fruits of Spondias spp. and characterized those enzymes in terms of temperature, optimum $\mathrm{pH}$, and stability. Additionally, we evaluated the conditions necessary for enzyme inactivation through the application of response surface statistical methodology.

\section{Materials and methods}

\subsection{Preparation of the crude extract}

The fruits of Spondias spp. (5 Kg) were acquired in the Central Market in the city of Feira de Santana, Bahia State, Brazil. The fruits were washed with distilled water, the hard endocarp was removed, and the pulp (together with the thin skin) was homogenized in a blender. The resulting mixture was centrifuged at $4,000 \mathrm{rpm}$ at $10^{\circ} \mathrm{C}$ for 15 minutes and the supernatant $\left(1.5 \mathrm{~mL}\right.$ aliquots) was maintained frozen $\left(-18^{\circ} \mathrm{C}\right)$ until used as crude enzymatic extracts in the subsequent tests.

\subsection{Determination of peroxidase and polyphenol-oxidase activities}

The peroxidase activity of the Spondias spp. extract was determined according to the modified methodology of Khan and Robinson (1994). The substrate was composed of $2.850 \mathrm{~mL}$ phosphate buffer $(50 \mathrm{mM}, \mathrm{pH} 7.0)$ and $0.015 \mathrm{ml}$ of an ethyl alcohol solution of guaiacol $(0.5 \%)$, maintained in a water bath at $25^{\circ} \mathrm{C}$. The reaction was initiated by the addition of $0.010 \mathrm{~mL}$ of the enzymatic extract and $0.450 \mathrm{ml}$ of $\mathrm{H}_{2} \mathrm{O}_{2}(1 \%)$. The spectral absorption at $470 \mathrm{~nm}$ was determined using a spectrophotometer (Biospectro SP-220) after 5 minutes of reaction and compared with a control cell in which the $\mathrm{H}_{2} \mathrm{O}_{2}$ solution was substituted by water. One unit of peroxidase activity $(\mathrm{U})$ was defined as the amount of enzyme necessary to cause an increase of 0.001 in the absorption for each minute of reaction time.

In order to determine the polyphenol-oxidase activity, the modified method of Fujita et al. (1995) was used. The substrate was composed of $2.3 \mathrm{~mL}$ of phosphate buffer $(50 \mathrm{mM}, \mathrm{pH} 7.0$ ) and $0.6 \mathrm{~mL}$ of pyrocatechol solution $(100 \mathrm{mM})$ and maintained in a water bath at $25^{\circ} \mathrm{C}$. The reaction was initiated by the addition of $0.100 \mathrm{~mL}$ of the enzyme extract. The spectral absorption at $425 \mathrm{~nm}$ was determined using a spectrophotometer (Biospectro SP-220) after 10 minutes of reaction and compared with a control cell in which the enzyme extract was substituted by water. One unit of polyphenol-oxidase (U) was defined as the amount of enzyme necessary to cause an increase of 0.001 in the absorption for each minute of reaction time.

The following equation was used to calculate oxidase activity: (Equation 1)

Activity $\left(\mathrm{U} \mathrm{ml}^{-1}\right)=\left[\left(\mathrm{AF}_{\text {sample }}-\mathrm{AI}_{\text {sample }}\right)-\left(\mathrm{AF}_{\text {blank }}-\mathrm{AI}_{\text {blank }}\right)\right] /(0.001 \times \mathrm{t})$

where, $\mathrm{AF}_{\text {sample }}$ is the final absorption of the sample, $\mathrm{AI}_{\text {sample }}$ is the initial absorption of the sample, $\mathrm{AF}_{\text {blank }}$ is the final absorption of the control, $\mathrm{AI}_{\text {blank }}$ is the initial absorption of the control, and $\mathrm{t}$ is the reaction time in minutes.

\subsection{Biochemical characterization of the oxidases}

\section{Effect of $\mathrm{pH}$ and temperature on enzymatic activity}

The optimal $\mathrm{pH}$ value for peroxidase and polyphenoloxidase activity in Spondias spp. extracts was determined by measuring their enzymatic activity (as described above) at $\mathrm{pH}$ values between 2.0 and 9.0 (at intervals of $1.0 \mathrm{pH}$ unit) at $25^{\circ} \mathrm{C}$. The optimal temperature for the enzymatic activity was then evaluated by determining the enzymatic activity at temperatures between 10 and $90^{\circ} \mathrm{C}$ (at intervals of $10^{\circ} \mathrm{C}$ ) - at the $\mathrm{pH}$ value determined as optimal for each enzyme.

\section{Effects of $\mathrm{pH}$ and temperature on enzyme stability}

Enzymatic stability at varying $\mathrm{pH}$ values was determined by incubating aliquots of $1 \mathrm{~mL}$ of the enzyme extract with $1 \mathrm{~mL}$ of the buffer solution $(200 \mathrm{mM})$ at $\mathrm{pH}$ values varying from 3.0 to 10.0 , at $10^{\circ} \mathrm{C}\left( \pm 1^{\circ} \mathrm{C}\right)$. Residual activity was determined after 24 hours of incubation under conditions considered optimal for the activity of each enzyme (for peroxidase: $\mathrm{pH} 5.0$ and $30^{\circ} \mathrm{C}$; for polyphenol-oxidase: $\mathrm{pH} 7.0$ and $40{ }^{\circ} \mathrm{C}$ ).

For studies of the thermo-stability of the enzymes, aliquots of the crude extract were incubated at temperatures between 10 and $90{ }^{\circ} \mathrm{C}$ (intervals of $10^{\circ} \mathrm{C}$ ) and at boiling temperature $\left(97^{\circ} \mathrm{C} \pm 2\right)$ for one hour. The samples were cooled in an ice-bath, and the residual activity was determined under the conditions found to be optimal for each oxidase.

\section{Statistical analysis}

All assays were performed in triplicate. The significance of the results and statistical differences were analyzed using the SISVAR free software. The data were analyzed by variance analysis. The Scott-Knott test was applied to determine the differences among means with a level of significance of 0.05 .

\subsection{Examination of oxidase inactivation}

To evaluate the Spondias spp. peroxidase and polyphenoloxidase inactivation, a factorial experimental design was applied testing three variables: ascorbic acid concentration, temperature, and extent of the heat treatment. Tests were performed according to the model generated by the Statistica (6.0) software package (Table 1), which was also used to evaluate the ANOVA results and to generate the response surfaces.

All reagents applied were of analytical grade.

\section{Results and discussion}

\subsection{Peroxidases}

The peroxidases of Spondias spp. demonstrated optimal activity at pH 5.0 (no significant difference was found among the results obtained for $\mathrm{pH}$ values between 4.0 and 6.0) and low activity at $\mathrm{pH}$ values higher than 7.0 or lower than 4.0 (Figure 1). The highest activity of these peroxidases at acid $\mathrm{pH}$ levels is in accordance with essentially all recently published literature: the peroxidases of pineapples (BRITO et al., 2005), vanilla 
(MARQUEZ et al., 2008) and Copaifera langsdorffii leaves (MACIEL; GOUVÊA; PASTORE, 2006) demonstrate optimal levels of activity at $\mathrm{pH} 4.5,3.8$ and 5.5 respectively. However, the peroxidases of the kiwifruit demonstrate optimal activity values in the $\mathrm{pH}$ range between 6.0 and 8.5 (FANG et al., 2008).

The optimal temperature for the peroxidase activity was found to be $30{ }^{\circ} \mathrm{C}$ (Figure 1). The optimal temperature for the peroxidase activity in other plants is apparently extremely variable, with values of $50^{\circ} \mathrm{C}$ being registered for two different varieties of pineapples (BRITO et al., 2005) but $16^{\circ} \mathrm{C}$ for vanilla (MARQUEZ et al., 2008).

Both graphs of peroxidase activity (optimal temperature and $\mathrm{pH}$ - Figure 1) indicated the probable presence of isoforms in the crude extract. One of the isoenzymes present in Spondias spp. apparently has an optimal functional temperature of $60{ }^{\circ} \mathrm{C}$, a value higher than those previously reported. The presence of peroxidase isoenzymes is very common in plant tissues (WHITAKER, 1994), and it was reported for kiwifruits (FANG et al., 2008), guava (ZANATTA;

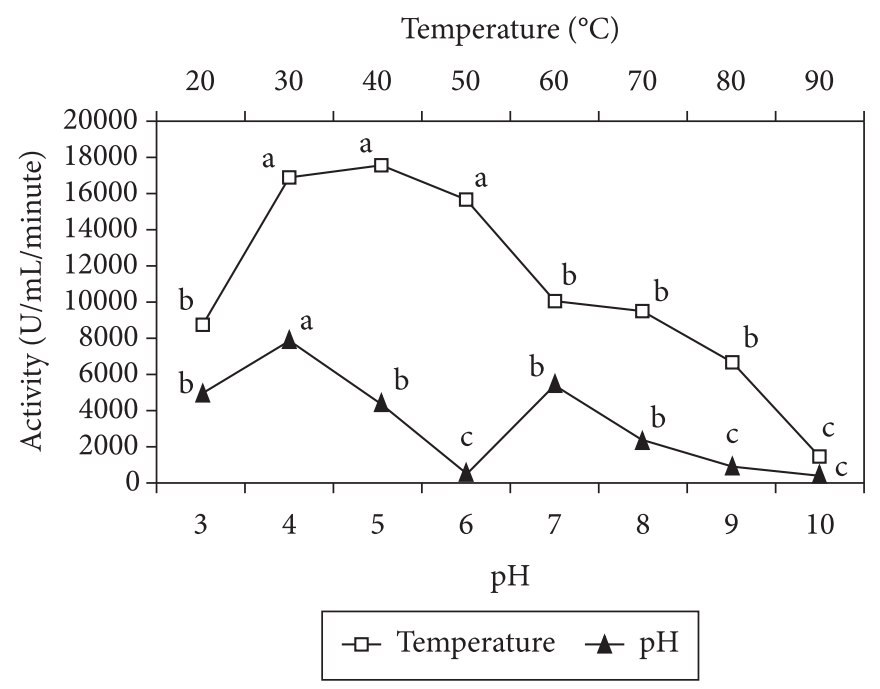

Figure 1. Effects of $\mathrm{pH}$ and temperature on the peroxidase activity in crude extracts of Spondias spp. Same letters indicate no significant difference by the Scott-Knott test with a level of significance of 0.05 .
ZOTARELLI; CLEMENTE, 2006) and apples (VALDERRAMA; MARANGONI; CLEMENTE, 2001). Nevertheless, isoenzymes were not found in crude extracts of pineapples (variety IACgomo de mel, and the clone IAC-1) (BRITO et al., 2005).

The total activity value found for the peroxidases of Spondias spp. under the conditions determined as optimal $(\mathrm{pH}=5.0$ and temperature $=30^{\circ} \mathrm{C}$ ) was $7,946.67 \mathrm{U} / \mathrm{mL} /$ minute, which was considerably higher than the values reported for other fruits: $4.05 \mathrm{U} / \mathrm{mL} / \mathrm{minute}$ for guava (ZANATTA; ZOTARELLI; CLEMENTE, 2006); 5.60 and $5.24 \mathrm{U} / \mathrm{mL} /$ minute for different varieties of grapes (FREITAS et al., 2008); and 5.97 and $6.05 \mathrm{U} / \mathrm{mL} / \mathrm{minute}$ for soluble and bound peroxidase in avocado (LUÍZ et al., 2007). An exception was the work by Maciel, Gouvêa and Pastore (2006), in which the authors reported peroxidase activity of approximately $60,000 \mathrm{U} / \mathrm{mL} /$ minute in Copaifera langsdorffii leaves.

The peroxidases of Spondias spp. were found to be stable in the $\mathrm{pH}$ range from 3.0 to 10.0 , and the residual activity remained mostly above $60 \%$ (Figure 2 ). The high $\mathrm{pH}$ stability found does

Temperature $\left({ }^{\circ} \mathrm{C}\right)$

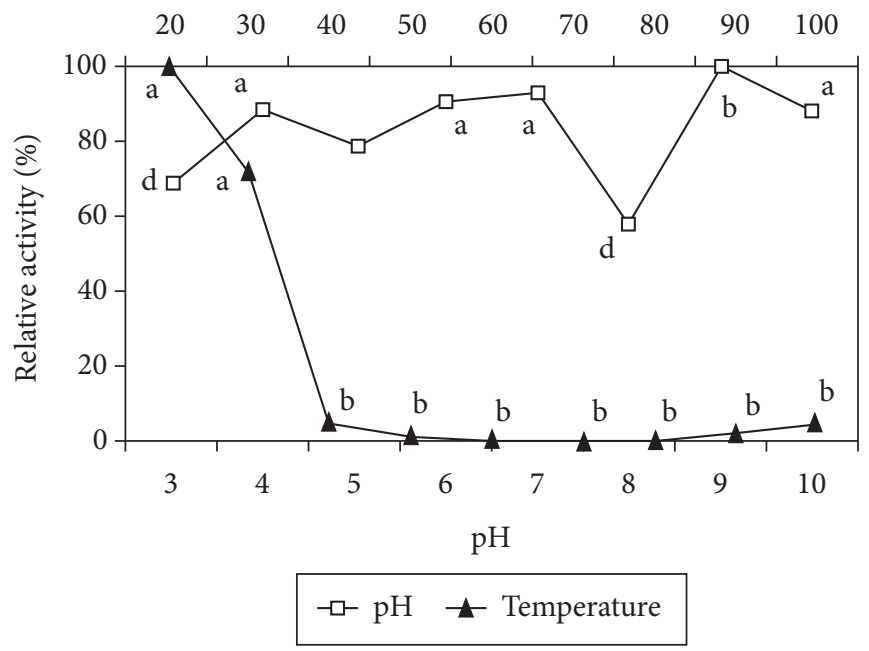

Figure 2. Effect of $\mathrm{pH}$ and temperature on the peroxidase stability in crude extracts of Spondias spp. Same letters indicate no significant difference by the Scott-Knott test with a level of significance of 0.05 .

Table 1. Experimental panning and results for oxidases inactivation.

\begin{tabular}{|c|c|c|c|c|c|}
\hline Trial & $\begin{array}{c}\text { Temperature } \\
\left({ }^{\circ} \mathrm{C}\right)\end{array}$ & $\begin{array}{c}\text { Time } \\
\text { (minute) }\end{array}$ & $\begin{array}{l}\text { Acid conc. } \\
\left(\mathrm{mg} \cdot \mathrm{L}^{-1}\right)\end{array}$ & $\begin{array}{c}\text { Peroxidase } \\
(\mathrm{U} / \mathrm{mL} / \text { minute })\end{array}$ & $\begin{array}{c}\text { Polyphenol-oxidase } \\
\text { (U/mL/minute) }\end{array}$ \\
\hline 1 & 100 & 5 & 200 & 0.00 & 0.0 \\
\hline 2 & 100 & 5 & 0 & 140.00 & 14.0 \\
\hline 3 & 100 & 1 & 200 & 240.00 & 9.0 \\
\hline 4 & 100 & 1 & 0 & 40.00 & 17.0 \\
\hline 5 & 50 & 5 & 200 & 506.67 & 137.0 \\
\hline 6 & 50 & 5 & 0 & 1146.67 & 180.0 \\
\hline 7 & 50 & 1 & 200 & 13813.33 & 107.0 \\
\hline 8 & 50 & 1 & 0 & 11706.00 & 143.0 \\
\hline 9 & 75 & 3 & 100 & 20.00 & 5.0 \\
\hline 10 & 75 & 3 & 100 & 0.00 & 15.0 \\
\hline 11 & 75 & 3 & 100 & 60.00 & 9.0 \\
\hline
\end{tabular}


not appear to be exceptional since the peroxidase activity in two different pineapple varieties (BRITO et al., 2005) were higher than $90 \%$ in the $\mathrm{pH}$ range of 4.0 to 9.0 after incubation for 24 hours at $50{ }^{\circ} \mathrm{C}$. The peroxidases of vanilla retained more than $60 \%$ of their activity when maintained at $\mathrm{pH}$ values between 5.0 and 12.0 (MARQUEZ et al., 2008).

After a 60 minute-treatment, the peroxidases of Spondias spp. maintained more than $60 \%$ of their residual activity at temperatures between 20 and $30{ }^{\circ} \mathrm{C}$, but they were essentially inactive at temperatures above $40{ }^{\circ} \mathrm{C}$ (Figure 2). Complete inactivation, however, was not attained even at boiling temperature: values between 0.95 and $5.07 \%$ of residual activity were recorded at temperatures above $60{ }^{\circ} \mathrm{C}$ indicating the presence of thermo-resistant isoforms of this enzyme (no assay replicate showed under $20 \mathrm{U} / \mathrm{mL} /$ minute activity). The peroxidases of pineapples were also found to be thermo-stable retaining residual activity higher than $60 \%$ after 30 minutes of treatment at $60{ }^{\circ} \mathrm{C}$ and becoming inactive only at $80^{\circ} \mathrm{C}$ (BRITO et al., 2005). The peroxidases of vanilla were stable at temperatures below $30{ }^{\circ} \mathrm{C}$ (maintaining more than $60 \%$ of their activity) but became completely inactive at $70{ }^{\circ} \mathrm{C}$ at $\mathrm{pH}=11.0$ (MARQUEZ et al., 2008).

\subsection{Polyphenol-oxidases}

The optimal activity of the polyphenol-oxidases of Spondias spp. was observed at $\mathrm{pH} 7.0$, with lower activity levels occurring at more acidic or alkaline $\mathrm{pH}$ values (Figure 3 ). These results were identical to those reported by Dogan, S., Turan and Dogan, M. (2006), who investigated the polyphenol-oxidase activity in thyme (Thymbra spicata, an herb used in Turkey to prepare tea and as a condiment for certain types of cheese). Similar results were reported by Gomes et al. (2001), who determined that the optimal $\mathrm{pH}$ for polyphenol-oxidase activity in various black bean varieties was 7.2. Fang et al. (2007) determined the

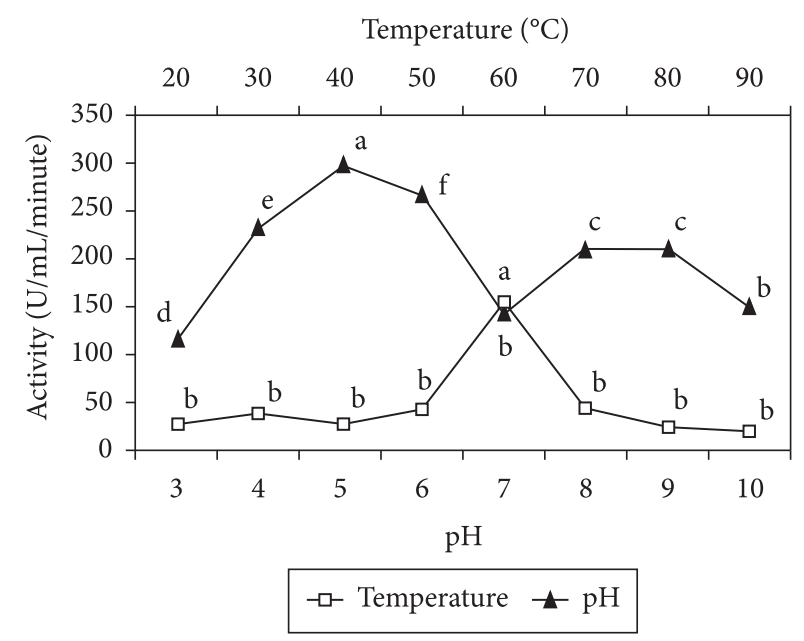

Figure 3. Effect of $\mathrm{pH}$ and temperature on the polyphenol-oxidase activity in crude extracts of Spondias spp. Same letters indicate no significant difference by the Scott-Knott test with a level of significance of 0.05 . optimal pH for bayberry to be 6.0 (Myrica rubra, a fruit similar to the strawberry, which has great economic importance in China), while Espín, Tudela and Garcia-Canovas (1997) determined that pH 5.0 was optimal for artichoke.

The optimal temperature found for polyphenol-oxidase activity in Spondias spp. was $40^{\circ} \mathrm{C}$ (Figure 3), a value equal to that reported for thyme (DOGAN, S.; TURAN; DOGAN, M., 2006), and similar to that found for bayberry $\left(30^{\circ} \mathrm{C}\right)$ (FANG et al., 2008).

The graph of polyphenol-oxidase activity at various temperatures indicates the probable presence of isoenzymes in the crude extract. Apparently, some of the isoenzymes found have high optimal temperature (between 70 and $80^{\circ} \mathrm{C}$ ). Similar data was not found in available published studies.

The total activity value observed for Spondias spp. polyphenol-oxidase under optimal conditions $(\mathrm{pH}=7.0$ and temperature $=40{ }^{\circ} \mathrm{C}$ ) was $301.0 \mathrm{U} / \mathrm{mL} /$ minute - which was found to be quite higher than the values published for other plants: $1.51 \mathrm{U} / \mathrm{mL} / \mathrm{minute}$ for guava (ZANATTA; ZOTARELLI; CLEMENTE, 2006); 5.60 and $5.24 \mathrm{U} / \mathrm{mL} /$ minute for different varieties of grapes (FREITAS et al., 2008); and between 10 and $14 \mathrm{U} / \mathrm{mL} / \mathrm{minute}$ for nine different varieties of beans (GOMES et al., 2001). Higher values were reported for thyme (2,700U/mL/mimute) (DOGAN, S.; TURAN; DOGAN, M. , 2006) and bayberry (509U/g/minute) (FANG et al., 2007).

The polyphenol-oxidases of Spondias spp. were stable at $\mathrm{pH}$ levels between 3.0 and 10.0 retaining residual activities above $60 \%$ (Figure 4). Lima et al. (2001) reported that polyphenol-oxidases in the pulp of mature Annona squamosa fruits were stable between $\mathrm{pH} 6.0$ and 7.5 retaining approximately $90 \%$ of their activity at $\mathrm{pH}$ levels between 6.0 and 8.0 - thus demonstrating much lower $\mathrm{pH}$ stability than the enzymes of Spondias spp.. The polyphenol-oxidase enzymes of Spondias spp. remained stable

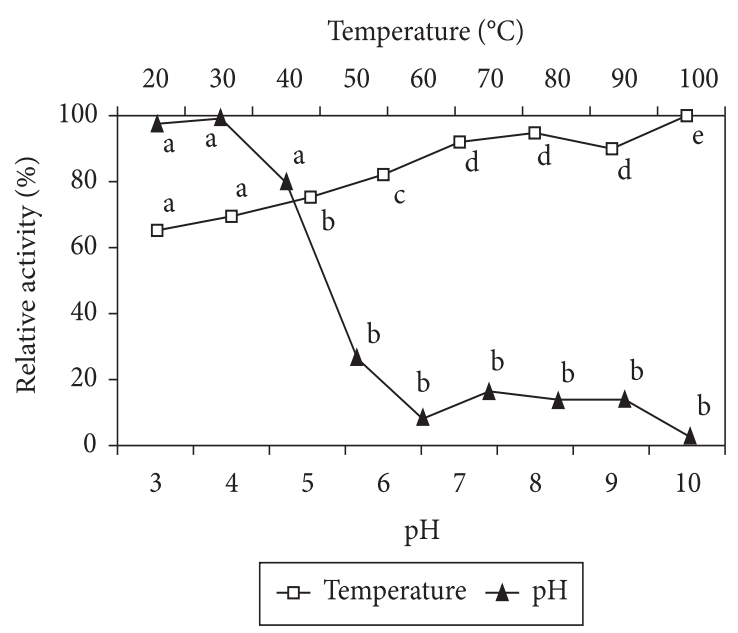

Figure 4. Effect of $\mathrm{pH}$ and temperature on the polyphenol-oxidase stability in crude extracts of Spondias spp. Same letters indicate no significant difference by the Scott-Knott test with a level of significance of 0.05 . 
at temperatures between 20 and $40{ }^{\circ} \mathrm{C}$ (Figure 4), with more than $70 \%$ of their residual activity. Less than $3 \%$ of its initial residual activity was retained after boiling (no assay replicate showed under $6 \mathrm{U} / \mathrm{mL} /$ minute activity). The residual activity observed after treatment at temperatures between 60 and $100^{\circ} \mathrm{C}$ is probably due to the thermal resistance of isoenzymes that have optimal activities in the highest temperature ranges. Lima et al. (2001) noted that the polyphenol-oxidases of mature Annona squamosa fruits were stable at temperatures between 10 and $30^{\circ} \mathrm{C}$ for one 1 hour, but they were rapidly inactivated at temperatures above $50{ }^{\circ} \mathrm{C}$. Polyphenol-oxidases from thyme maintained approximately $100 \%$ of their activity at temperatures below $55{ }^{\circ} \mathrm{C}$, but they were completely inactivated at $85{ }^{\circ} \mathrm{C}$ (DOGAN, S.; TURAN; DOGAN, M., 2006), while the enzymes of bayberry were inactivated at $90{ }^{\circ} \mathrm{C}$ (FANG et al., 2008).

\subsection{Examination of the inactivation of the polyphenol-oxidases and peroxidases of Spondias spp.}

The residual activity values obtained for the peroxidases and polyphenol-oxidases of Spondias spp. after test treatments can be seen in Table 1.

\section{Inactivation of the peroxidases}

The $\mathrm{R}^{2}$ value $\left(\mathrm{R}^{2}=0,89887\right)$ obtained can be considered excellent in terms of the tested material, and it indicates that $89.88 \%$ of the differences obtained between the results are due to the tested treatments, while only about $10 \%$ can be attributed to other factors (such as errors). The calculated $\mathrm{F}$ value $(5,925)$ could only be considered significant at a $90 \%$ level of significance, which can be considered acceptable for samples of high intrinsic variability (biological material).

Among the tested variables, treatment temperature and exposure time - as well as the interaction between these two variables - were considered significant for the inactivation of the peroxidases found in Spondias spp. (data not shown). The concentrations of ascorbic acid did not significantly influence inactivation thus indicating that the presence of this acid does not influence thermal destruction nor inhibit enzymatic action. This data is not in agreement with the results reported by Serrano-Martínez et al. (2008), who could not detect peroxidase activity in red peppers after adding small concentrations (less than $8 \mathrm{mg} . \mathrm{L}^{-1}$ ) of ascorbic acid to the reaction medium. These authors did not view the ascorbic acid as functioning directly as an inhibitor of the enzyme, but rather to reverse the oxidation of the substrate used (ABTS). In that case, the reaction product was the radical ABTS, which can be reverted by the presence of reducing agents. In the present study, guaiacol was used as the substrate, and the end-product measured was tetra-guaiacol. This end-product, once formed, could not be reversed by the simple presence of antioxidants.

According to the graph and the equation that describes them (Figure 5), it can be seen that the lowest temperature necessary to attain total inactivation of the peroxidases in this study is approximately was $71^{\circ} \mathrm{C}\left(71.3738^{\circ} \mathrm{C}\right)$, and that this temperature must be maintained for at least five minutes. As the treatment temperature increases, the exposure time can be reduced while still attaining the same effect: $80^{\circ} \mathrm{C} / 4.23$ minutes, $90^{\circ} \mathrm{C} / 3.34$ minutes, and $100^{\circ} \mathrm{C} / 2.45$ minutes. The peroxidases of Spondias spp. appeared to be more resistant to thermal destruction than the enzymes found in the pineapples (BRITO et al., 2005), which were destroyed by treatment at $80{ }^{\circ} \mathrm{C}$ for 3 minutes; or those of mint leaves (SHALINI; SHIVHARE; BASU, 2008), which were inactivated at $80^{\circ} \mathrm{C}$ within 30 seconds.

\section{Inactivation of polyphenol-oxidases}

The $\mathrm{R}^{2}$ value $(0,79626)$ obtained can be considered very good in terms of the tested material, and it indicates that $79.62 \%$ of the differences obtained among the results are due to the test treatments, while only approximately $20 \%$ can be attributed to other factors (such as errors). The calculated $\mathrm{F}$ value $(2,605)$ could not be considered significant at a $90 \%$ level of significance, which may be explained by the "lack of fit" - a residual component that, in this case, appeared significant and refers to the adjustment of the tested points in relation to the response surface generated by the software. In general, the lack of fit refers more to the predictability of the enzyme behavior in terms of the variables of time, temperature, and acid concentration which were not tested than the significance of the values actually tested. Hence, the data can be accepted, but only the tested values should be considered.

Among the tested variables, only the temperature of the heat treatment was considered significant in terms of the inactivation of polyphenol-oxidases from Spondias spp. (data not shown). Neither the extent of the treatment nor the presence of ascorbic acid appeared to influence the observed decreases in enzymatic activity.

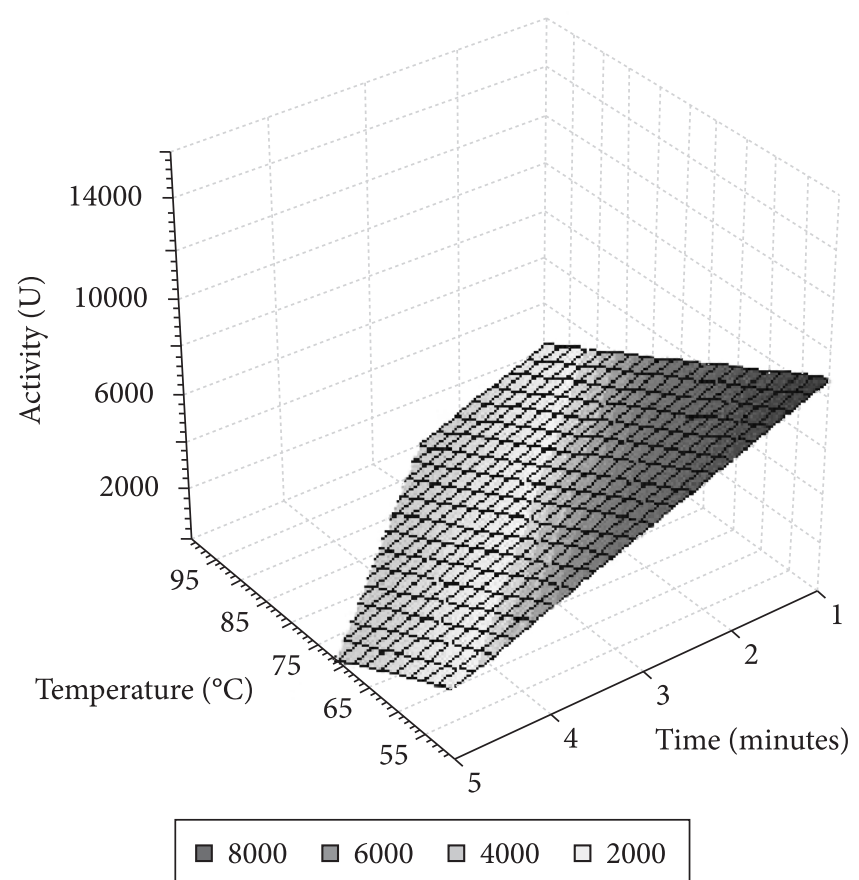

Figure 5. Effects of time and temperature on the inactivation of peroxidases present in crude extracts of Spondias spp. Activity $(\mathrm{U})=$ $17049.072-133.7633^{\star} \mathrm{x}-1500.375^{\star} \mathrm{y}$ 
According to the obtained response surface (Figure 6), although the presence of ascorbic acid was not considered significant, this compound did, in fact, influence the inactivation temperature of the polyphenol-oxidases in Spondias spp. The lowest temperature necessary for the inactivation of the enzymes in those tests was $92{ }^{\circ} \mathrm{C}\left(92.1473{ }^{\circ} \mathrm{C}\right)$, when $200 \mathrm{mg} \cdot \mathrm{L}^{-1}$ of ascorbic acid was added to the reaction mixture. With lower concentrations of this acid, higher treatment temperatures were necessary: $100 \mathrm{mg} \cdot \mathrm{L}^{-1}-96^{\circ} \mathrm{C}$.

According to Martinez and Whitaker (1995), sulfites and ascorbic acid are the main inhibitors of polyphenol-oxidases from plants and mushrooms since they act directly on the enzymes active site and also reduce the reaction products formed. However, since sulfites can elicit allergic reactions in some consumers, their use is controlled and not recommended. Dogan, S., Turan and Dogan, M. (2006) tested glutathione and L-cysteine as inhibitors of polyphenol-oxidases in thyme, and glutathione was considered the most effective.

Thus, to inactivate the suite of peroxidases and polyphenoloxidases found in Spondias spp., it is necessary to heat the pulp at $92{ }^{\circ} \mathrm{C}$ in the presence of $200 \mathrm{mg} \cdot \mathrm{L}^{-1}$ ascorbic acid for approximately 3.15 minutes ( 3.1479 minutes, according to the equation in Figure 3). Alternatively, $100 \mathrm{mg} . \mathrm{L}^{-1}$ of ascorbic acid could be added and the heat treatment slightly increased to $96^{\circ} \mathrm{C}$ for 2.80 minutes (2.8044). High temperatures are required due to the presence of isoforms with high temperature optima and probably high stability, and they accounted for by the residual activity found in the thermo-stability tests of both oxidases.

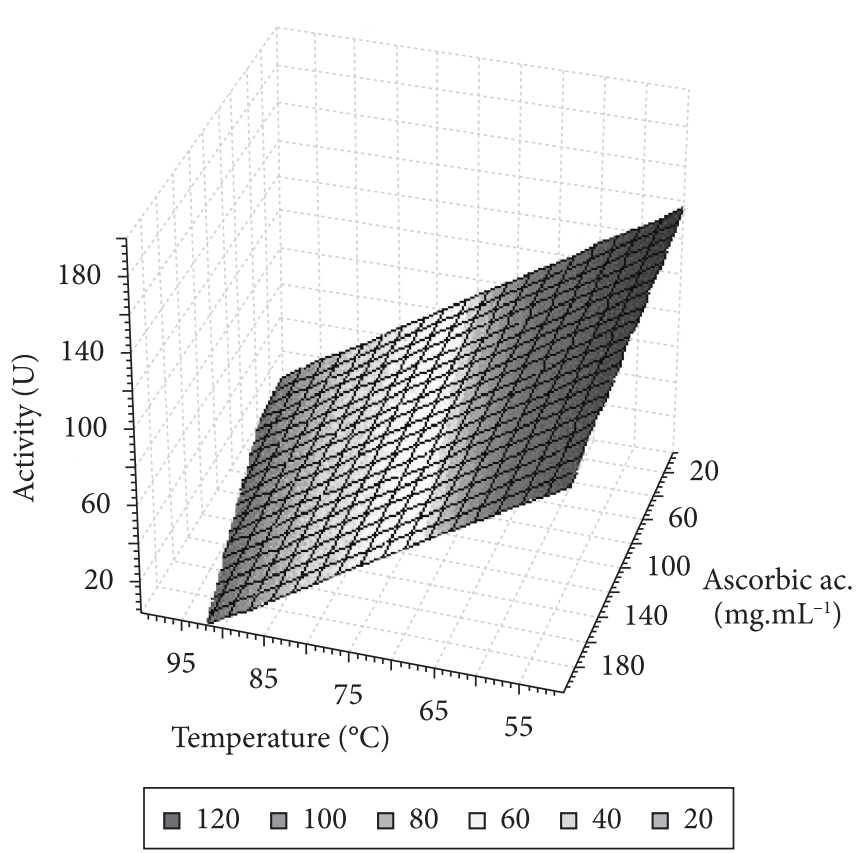

Figure 6. Effects of temperature and the concentrations of ascorbic acid on the inactivation of polyphenol-oxidases in crude extracts of Spondias spp.

\section{Conclusions}

The present work described for the first time the characteristics of the peroxidases and polyphenol-oxidases in Spondias spp. and the conditions necessary for their inactivation.

The peroxidases of Spondias spp. showed a total activity of $7,946.67 \mathrm{U} / \mathrm{mL} / \mathrm{minute}$ at $\mathrm{pH}$ and temperature optima of 5.0 and $30^{\circ} \mathrm{C}$, respectively. The presence of isoforms with activity optima at $60^{\circ} \mathrm{C}$ was also observed. These enzymes demonstrate high stability at all $\mathrm{pH}$ values between 3.0 and 10.0, maintaining more than $60 \%$ of residual activity. The peroxidases maintained more than $60 \%$ of their activity after incubation for 60 minutes at temperatures below $30^{\circ} \mathrm{C}$.

The polyphenol-oxidases of Spondias spp. presented a total activity of $301.0 \mathrm{U} / \mathrm{mL} /$ minute at $\mathrm{pH}$ and temperature optima of 7.0 and $40^{\circ} \mathrm{C}$, respectively. The presence of isoenzymes with activity optima between 70 and $80^{\circ} \mathrm{C}$ was also observed. These enzymes demonstrated high stability at $\mathrm{pH}$ values between 3.0 and 10.0 , maintaining more than $60 \%$ of residual activity. The polyphenol-oxidases maintained more than $70 \%$ of their activity after incubation for 60 minutes at temperatures below $40{ }^{\circ} \mathrm{C}$.

To inactivate the suite of peroxidases and polyphenoloxidases in Spondias spp. either of the following alternative treatment regimes can be applied: $200 \mathrm{mg} \cdot \mathrm{L}^{-1}$ of ascorbic acid at $92^{\circ} \mathrm{C}$ for 3.15 minutes; or $100 \mathrm{mg} . \mathrm{L}^{-1}$ of ascorbic acid at $96^{\circ} \mathrm{C}$ for 2.80 minutes.

\section{References}

BRITO, C. A. K. et al. Biochemical characteristics peroxidase from pineapple (Ananas comosus (1.) Merrill): cultivar IAC gomo-de-mel and clone IAC-1. Ciência e Tecnologia de Alimentos, v. 25, n. 2, p. 244-2498, 2005.

CEVA-ANTUNES, P. M. N. et al. Analysis of volatile composition of siriguela (Spondias purpurea L.) by Solid Phase Micro Extraction (SPME). Lebensmittel Wissenschaft und Technologie, v. 39, n. 4, p. 436-442, 2006.

DOGAN, S.; TURAN, P.; DOGAN, M. Some kinetic properties of polyphenol oxidase from Thymbra spicata L. var. spicata. Process Biochemistry, v. 41, n. 12, p. 2379-2385, 2006.

ESPÍN, J. C.; TUDELA, J.; GARCIA-CANOVAS, F. Monophenolase Activity of Polyphenol Oxidase from Artichoke Heads (Cynara scolymus L.). Lebensmittel Wissenschaft und Technologie, v. 30, n. 8, p. 819-825, 1997.

FANG, Z. et al. Polyphenol oxidase from bayberry (Myrica rubra Sieb. et Zucc.) and its role in anthocyanin degradation. Food Chemistry, v. 103, n. 2, p. 268-273, 2007.

FANG, L.; JIANG, B.; ZHANG, T. Effect of combined high pressure andthermal treatment on kiwifruit peroxidase. Food Chemistry, v. 109,n. 4, p. 802-807, 2008.

FREITAS, A. A. et al. Effect of peroxidase (POD) and polyphenoloxidase enzymes (PPO) on Benitaka and Rubi grape cultivars and on products processed in the form of juice and jelly. Ciência e Tecnologia de Alimentos, v. 28, n. 1, p. 172-177, 2008.

FUJITA, S. et al. Purification and properties of polyphenol oxidase from cabbage (Brassica oleraceae L.). Journal of Agriculture and Food Chemistry, v. 43, n. 5, p. 1138-1142, 1995.

GOMES, M. R. A. et al. Physical chemical properties of polyphenoloxidase from beans (Phaseolus vulgaris L.). Ciência e Tecnologia de Alimentos, v. 21, n. 1, p. 69-72, 2001. 
KHAN, A. A.; ROBINSON, D. S. Hydrogen donor specifity of mango isoperoxidases. Food Chemistry, v. 49, n. 4, p. 407-410, 1994.

LIMA, E. D. P. A. et al. Obtaining and use of polyphenol-oxidase enzyme extracted from ripe custard apple (Annona squamosa L.) pulp on the cocoa (Theobroma cacao L.) nibs in taste improvement. Revista Brasileira de Fruticultura, v. 23, n. 3, p. 709-713, 2001.

LUÍZ, R. C. et al. Kinetic of inactivation of polyphenol-oxidase and peroxidase of avocado (Persea americana Mill.). Ciência e Agrotecnologia, v. 31, n. 6, p. 1766-1773, 2007.

MACIEL, H. P. F.; GOUVÊA, C. M. C. P.; PASTORE, G. M. Obtention of a new source of peroxidase from Copaifera langsdorffi leaf, desf. with high activity. Ciência e Tecnologia de Alimentos, v. 26, n. 4, p. 735-739, 2006.

MARTINEZ, M. V.; WHITAKER, J. R. The biochemistry and control of enzymatic browning. Trends in Food Science \& Technology, v. 6, n. 6, p. 195-200, 1995.

MARQUEZ, O. et al. Purification and characterization of cell wallbound peroxidase from vanilla bean. Lebensmittel Wissenschaft und Technologie, v. 41, n. 8, p. 1372-1379, 2008.

SERRANO-MARTÍNEZ, A. et al. Kinetic characterization and thermal inactivation study of partially purified red pepper (Capsicum annuum L.) peroxidase. Food Chemistry, v. 107, n. 1, p. 193-199, 2008.
SHALINI, G. R.; SHIVHARE, U. S.; BASU, S. Thermal inactivation kinetics of peroxidase in mint leaves. Journal of Food Engineering, v. 85, n. 1, p. 147-153, 2008.

TEIXEIRA, G. H. A. et al. Use of modified atmosphere to extend shelf life of fresh-cut carambola (Averrhoa carambola L. cv. Fwang Tung), Postharvest Biology and Technology, v. 44, n. 1, p. 80-85, 2007.

USHIKUBO, F. Y.; WATANABE, A. P.; VIOTTO, L. A. Microfiltration of umbu (Spondias tuberosa Arr. Cam.) juice. Journal of Membrane Science, v. 288, n. 1-2, p. 61-66, 2007.

VALDERRAMA, P.; MARANGONI, F.; CLEMENTE, E. Effect of thermal treatments on peroxidase (POD) and polyphenol-oxidase (PPO) activities of apple (Mallus comunis). Ciência e Tecnologia de Alimentos, v. 21, n. 3, p. 321-325, 2001.

WHITAKER, J. R. Catalase and Peroxidase. In: WHITAKER, J. R. (Ed.). Principles of Enzymology for the Food Sciences. New York: Dekker, 1994.

ZANATTA, C. L.; ZOTARELLI, M. F.; CLEMENTE, E. Peroxidase (POD) and polyphenol-oxidase (PPO) in guava (Psidium Guajava R.) pulp. Ciência e Tecnologia de Alimentos, v. 26, n. 3, p. 705-708, 2006.

ZAWISTOWSKI, J.; BILIADERIS, C. G.; ESKIN, N. A. M. Polyphenol oxidase. In: ROBINSOM, D.S.; ESKIN, N. A. M.(Ed.). Oxidative Enzymes in Foods. London: Elsevier, 1995. p. 217-271. 